\title{
A Model for Estimating Rest Completion for 'Nijisseiki' Pear
}

\author{
Fumio Tamura, Kenji Tanabe and Akihiro ItaI \\ Faculty of Agriculture, Tottori University, Koyama-cho, Tottori 680, Japan
}

(Received January 9, 1997)

\begin{abstract}
A chill unit model for 'Nijisseiki' pear was developed for prediction of leaf bud rest completion under Koyama and Saji conditions. The model assigns full effect for chilling accumulation for temperatures below $8^{\circ} \mathrm{C}$ until its value reaches 1200 , and then it cuts the lower temperature below $-4.0^{\circ} \mathrm{C}$ off for chilling accumulation. The model is more suitable in predicting rest completion of 'Nijisseiki' pear than previously reported models. By using the model, it is suggested that chilling requirement of leaf bud of 'Nijisseiki' pear should be 1400 chill unit.
\end{abstract}

\section{INTRODUCTION}

Forcing cultivation of Japanese pear (Pyrus pyrifolia Nakai) aiming at shipment early in the season has increased in recent years in Japan (Gemma, 1995). However, the lack of low temperature for the chilling requirement of bud rest inhibits the normal growth of new organs such as flower, current shoot or fruit of deciduous fruit trees (Westwood, 1978 ; Saure, 1985). Therefore, the prediction of rest completion is one of the most important factors in performing forcing culture in Japanese pear.

Quantitative measurements of the chilling requirement of deciduous fruit trees for rest completion have been reported by many authors (Richardson et al., 1974; Shaltout and Unrath, 1983 ; Asano and Okuno, 1990). Richardson et al. (1974) proposed a weighted chill unit $(\mathrm{CU})$ model in peach where $1.0 \mathrm{CU}$ equals $1 \mathrm{~h}$ of exposure at $6^{\circ} \mathrm{C}$. Asano and Okuno (1990), working with Japanese pear 'Hosui' and 'Kosui,' found that about $700 \mathrm{~h}$ of exposure to temperatures between $2^{\circ} \mathrm{C}$ and $10^{\circ} \mathrm{C}$ broke bud rest. They also demonstrated a $\mathrm{CU}$ model in 'Hosui' and 'Kosui' pears under Saitama conditions. The model assigned temperatures below $10^{\circ} \mathrm{C}$ were equally effective for bud break, while temperatures above $15^{\circ} \mathrm{C}$ reversed the chilling effect.

In contrast, our previous studies using excised 'Nijisseiki' pear shoots $(1993,1995)$ showed that the temperature of $5^{\circ} \mathrm{C}$ was the most effective in breaking leaf bud rest and $1400 \mathrm{~h}$ of exposure to $5^{\circ} \mathrm{C}$ broke the leaf bud rest completely. In addition, the results showed temperature of $10^{\circ} \mathrm{C}$ was as effective as $15^{\circ} \mathrm{C}$, whereas $10^{\circ} \mathrm{C}$ was less effective than $5^{\circ} \mathrm{C}$. Therefore, it seems that the effective temperatures for breaking bud rest of 'Nijisseiki' pear differ from 'Hosui' and 'Kosui' pears.

The objective of this study was to develop an accumulation model in predicting rest completion of 'Nijisseiki' pear under Tottori conditions.

\section{MATERIALS AND METHODS}

'Nijisseiki' pear shoots were collected periodically from mature trees growing at Koyama 
Table 1 Actual temperature and corresponding chill unit value of the Tottori model.

\begin{tabular}{|c|c|c|c|}
\hline \multicolumn{4}{|c|}{ Period } \\
\hline \multicolumn{2}{|c|}{$0-1200$ chill unit } & \multicolumn{2}{|c|}{1200 chill unit- } \\
\hline $\begin{array}{l}\text { Temp. } \\
\left({ }^{\circ} \mathrm{C}\right)\end{array}$ & $\begin{array}{l}\text { Chill unit } \\
\text { contribution }\end{array}$ & $\begin{array}{l}\text { Temp. } \\
\left({ }^{\circ} \mathrm{C}\right)\end{array}$ & $\begin{array}{l}\text { Chill unit } \\
\text { contribution }\end{array}$ \\
\hline$<8.0$ & 1.0 & $<-4.0$ & 0.0 \\
\hline $8.1-10.0$ & 0.8 & $-3.9--2.0$ & 0.6 \\
\hline $10.1-12.0$ & 0.6 & $-1.9-0$ & 0.8 \\
\hline $12.1-14.0$ & 0.2 & $0.1-8.0$ & 1.0 \\
\hline $14.1-16.0$ & 0 & $8.1-10.0$ & 0.8 \\
\hline $16.1-18.0$ & -0.4 & $10.1-12.0$ & 0.6 \\
\hline $18.1-20.0$ & -0.8 & $12.1-14.0$ & 0.2 \\
\hline \multirow[t]{4}{*}{$20.1<$} & -1.0 & $14.1-16.0$ & 0 \\
\hline & & $16.1-18.0$ & -0.4 \\
\hline & & $18.1-20.0$ & -0.8 \\
\hline & & $20.1<$ & -1.0 \\
\hline
\end{tabular}

( 2 m elevation) during 1991-92, 1992-93, 1993-94, 1994-95 and 1995-96 seasons and at Saji ( $412 \mathrm{~m}$ elevation) during $1995-96$ season. The terminal $5-10 \mathrm{~cm}$ and basal $10-15 \mathrm{~cm}$ sections were cut off and upper cut surfaces were sealed with grafting wax. The cuttings were placed in the greenhouse at $18^{\circ}$ to $20^{\circ} \mathrm{C}$ and put into plastic containers with their bases submerged in a solution consisting of $3.0 \%(\mathrm{w} / \mathrm{v})$ 8-hydroxyquinoline citrate and $0.03 \%(\mathrm{w} / \mathrm{v})$ alminum sulfate. Data of bud development were obtained every $3 \mathrm{~d}$ and percentage of bud break (first visible green tip) was calculated after $21 \mathrm{~d}$ of forcing. According to the previous studies (Shaltout and Unrath, 1983 ; Tamura et al., 1993), the termination of rest was identified when percentage of bud break on forced cuttings plateaued with no further significant increase.

Ambient air temperatures were recorded by a thermograph in a screen placed $1.5 \mathrm{~m}$ above ground level in Tottori University Farm (Koyama) and Saji Astro Park (Saji) adjoining each sampled orchard.

Three models were used in this study to compute completion of chilling requirements : the Utah model (Richardson et al., 1974), the Saitama model (Asano and Okuno, 1990) and the Tottori model based on our previous studies (Tamura et al., 1993, 1995). The actual temperature and corresponding chill unit values of the Tottori model are presented in Table 1. To determine the $\mathrm{CU}$ accumulation for a $24 \mathrm{~h}$ period, each the temperature $15 \mathrm{~min}$ was converted to the equivalent values of chilling, then these values were added. Calculation of effective chilling hours began just after the day when the largest negative accumulation was attained in November.

\section{RESULTS}

The percentages of bud break decreased to near zero in mid November and then increased in early January in Koyama in any experimental season (Fig. 1). However, date of optimum bud break showed a maximum difference of $10 \mathrm{~d}$ by these years. In the Saji area, both decrease and increase in percentages of bud break occurred $10 \mathrm{~d}$ earlier than those occurring in Koyama in 1995-96 season.

Accumulated $\mathrm{CU}$ values were calculated by using the three methods on the days when termination of bud rest was determined (Table 2). The days of termination of bud rest were 27 Jan. 1991 ; 17 Jan. 1992; 18 Jan. 1993 ; 24 Jan. 1994 and 18 Jan. 1996 under Koyama conditions and 10 Jan. 1996 under Saji conditions. When the Utah model was used for 


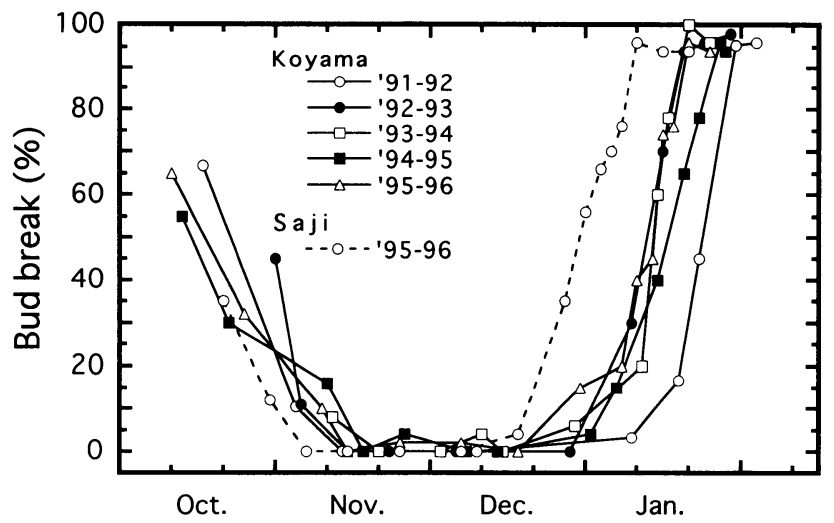

Fig. 1 Seasonal changes in percentages of leaf bud break on excised 'Nijisseiki' pear shoot in 1991 to 1996 seasons after 21-days forcing.

Table 2 Accumulated chill units for leaf bud break of 'Nijisseiki' pear using various models.

\begin{tabular}{lccccc}
\hline & & & \multicolumn{2}{c}{$\begin{array}{c}\text { Accumulated chill unit value } \\
\text { for leaf bud break }\end{array}$} \\
\cline { 4 - 6 } $\begin{array}{c}\text { Location (Tottori } \\
\text { prefecture) }\end{array}$ & Year & $\begin{array}{c}\text { Day of bud rest } \\
\text { termination }\end{array}$ & $\begin{array}{c}\text { Utah } \\
\text { model }\end{array}$ & $\begin{array}{c}\text { Saitama } \\
\text { model }\end{array}$ & $\begin{array}{c}\text { Tottori } \\
\text { model }\end{array}$ \\
\hline Koyama & $1991-1992$ & Jan 27, 1992 & 1057 & 1407 & 1407 \\
& $1992-1993$ & Jan 17, 1993 & 1028 & 1408 & 1386 \\
& $1993-1994$ & Jan 18, 1994 & 1143 & 1464 & 1408 \\
& $1994-1995$ & Jan 24, 1995 & 1041 & 1446 & 1399 \\
Saji & $1995-1996$ & Jan 18, 1996 & 1025 & 1433 & 1397 \\
Average & $1995-1996$ & Jan 9, 1996 & 649 & 1493 & 1405 \\
S.D. ${ }^{2}$ & & & 990 & 1442 & 1400 \\
& & & 158 & 31 & 8 \\
\hline
\end{tabular}

${ }^{2}$ Standard deviation.

calculation, $\mathrm{CU}$ values for bud break from year to year showed a maximum difference of 117 CU at Koyama, and a large difference of 377 CU appeared between Koyama and Saji in 199596 season. Maximum differences of $57 \mathrm{CU}$ and $60 \mathrm{CU}$ appeared with the Saitama model among the years and locations. On the contrary, when the Tottori model was used for calculation, $\mathrm{CU}$ values for bud break at Koyama were consistent from year to year with a maximum difference of $22 \mathrm{CU}$, and difference of $8 \mathrm{CU}$ was obtained between the locations.

\section{DISCUSSION}

Richardson et al., (1974) and Shaltout and Unrath (1983) proposed that accumulation of effective chilling hours be initiated just after the day when the largest negative accumulation was attained in fall. Calculations of $\mathrm{CU}$ in this study were performed according to these studies. Otherwise, Asano and Okuno (1990) proposed the Saitama model using chilling factor and seasonal factor together. The model initiated accumulate chilling on 5 Nov., the coefficients of season factor were 0.4 for date from 5 Nov. to 19 Nov., and then it assigned the season factor as 1.0 for dates after 20 Nov. From the data obtained under Koyama conditions, leaf buds on 'Nijisseiki' pear shoots did not enter their rest period in early November. Otherwise, leaf buds on shoot of 'Nijisseiki' pear growing at Saji area already stayed in rest in 
early November in 1995. Therefore, the seasonal factor may not apply to the trees growing at different locations and years.

Richardson et al. (1974) and Shaltout and Unrath (1983) pointed out that temperatures near $0^{\circ} \mathrm{C}$ had no effect on breaking bud rest of deciduous fruit trees. However, in this study, the Utah model assigning $0 \mathrm{CU}$ for temperatures below $1.4^{\circ} \mathrm{C}$ was not suitable for calculating chilling accumulation in 'Nijisseiki' pear under Koyama and Saji conditions. Compared with the Tottori model, the Saitama model was also not so suitable for calculating chilling accumulation in 'Nijisseiki' pear under Tottori conditions. The greatest difference between the Utah model and Saitama model was the constitution of the coefficients to determine the CU accumulation. In the former model, the temperatures below $1.4^{\circ} \mathrm{C}$ were cut off for $\mathrm{CU}$ accumulation, while the latter assigned $1.0 \mathrm{CU}$ for temperatures below $10^{\circ} \mathrm{C}$. Our previous study (Tamura et al., 1995) using 'Nijisseiki' pear shoots under constant temperatures showed $5^{\circ} \mathrm{C}$ was the most effective temperature in leaf bud break. We also observed that exposure to $5^{\circ} \mathrm{C}$ for $1400 \mathrm{~h}$ stimulated the break of bud rest completely. In addition, the percentage of bud break reached about $50 \%$ in both of the $0^{\circ} \mathrm{C}$ and $5^{\circ} \mathrm{C}$ treatments after 1000 and $1200 \mathrm{~h}$ of chilling, whereas further exposure to a temperature of $0^{\circ} \mathrm{C}$ showed little effect in bud break. Therefore, assigning CU below $5^{\circ} \mathrm{C}$ may be the reason for the failure of the Utah and Saitama models to predict rest completion of 'Nijisseiki' pear correctly.

To solve these problems, we developed the Tottori model based on our previous studies (Tamura et al., 1995) for prediction of rest completion in 'Nijisseiki' pear growing under Tottori conditions. The Tottori model consists of two CU models; one applies to the period until the day when $\mathrm{CU}$ accumulated to $1200 \mathrm{CU}$, and then another model is used for the calculation of $\mathrm{CU}$ accumulation. The former assigns $1.0 \mathrm{CU}$ for temperatures below $8^{\circ} \mathrm{C}$, the latter cut temperature below $-4.0^{\circ} \mathrm{C}$ off for $\mathrm{CU}$ accumulation and assigns a lower chilling contribution to the temperatures between $-3.9^{\circ} \mathrm{C}$ and $0^{\circ} \mathrm{C}$. At temperatures above $0^{\circ} \mathrm{C}$, both of the models consist of the same curve for determination of chilling effect. The Tottori model also differs from the Saitama model and Utah model at temperatures above $0^{\circ} \mathrm{C}$; it assigns a lower chilling contribution than the Saitama model to the temperatures between $8.0^{\circ}$ and $10.0^{\circ} \mathrm{C}$; it assigns a negative effect to temperatures above $16^{\circ} \mathrm{C}$. From the date obtained in this study, the Tottori model was more accurate in predicting rest completion of 'Nijisseiki' pear under Tottori conditions (Table 2).

By using the Tottori model, 1400 chill unit seemed to be needed to break leaf bud rest of 'Nijisseiki' pear. This result agrees with our previous studies (Tamura et al., 1993, 1995) performed under constant temperature.

We acknowledge the staff in Saji Astro Park for their support of the experiment.

\section{REFERENCES}

Asano, S., Okuno, T. 1990. Period of breaking the rest and the quality of chilling requirement of 'Kosui' and 'Hosui' Japanese pear. (Japanese text with English abstract) Bull. Saitama Hortic. Exp. Stn. $17: 41-47$.

Gemma, H. 1995. Dormancy breaking in Japanese pears grown in a heated greenhouse. Acta Hortic. 395 : 57-68.

Richardson, E. A., Seely, S. D., Walker, D. R. 1974. A model for estimating the completion of rest for 'Redheaven' and 'Elberta' peach trees. HortScience 9: 331-332.

Shaltout, A. D., Unrath, C. R. 1983. Rest completion prediction model for 'Starkrimson Delicious' apples. J. Am. Soc. Hortic. Sci. 180 : 957-964. 
Saure, M. C. 1985. Dormancy release in decidous fruit trees. Hort. Rev. 7 : 239-300.

Tamura, F., Tanabe, K., Ikeda, T. 1993. Relationship between intensity of bud dormancy and level of ABA in Japanese pear 'Nijisseiki.' (Japanese text with English abstract) J. Jpn. Soc. Hortic. Sci. 62 : 75-81.

Tamura, F., Tanabe, K., Itai, A. 1995. Effect of interruption of chilling on bud break in Japanese pear. Acta Hortic. 395: 135-140.

Westwood, M. N. 1978. Temperate-Zone Pomology. W. H. Freeman and Co., New York, p 199-303.

\section{〈和文抄録〉}

\section{ニホンナシ‘ニ十世紀’の自発休眠打破予測のための chill unit モデル}

\section{田村文男・田辺賢二・板井章浩}

\section{鳥取大学農学部}

鳥取県下の湖山および佐治地区においてニホンナシ“二十世紀”の芽の休眠打破を予測するため の chill unit モデルを検討した.このモデルは chill unit が 1200 に達するまでは $8{ }^{\circ} \mathrm{C}$ 以下の気温を 休眠打破に最も有効と評価して計算を行うが, それ以降の chill unit の積算には $-4.0^{\circ} \mathrm{C}$ 以下の気 温は効果が無いと評価するものである。このモデルは従来報告されている chill unit モデルよりニ ホンナシ “二十世紀’の休眠打破の予測に有効であり, “二十世紀”の低温要求量は 1400 chill unit と みなされた。 